\title{
Enlivening the Waterfront: Crime prevention through design
}

\author{
Mohd Zulhaimi Izwan Md Radzi1* ${ }^{*}$ Zarina Isnin², Zaharah Yahya² \\ 1, 2 Faculty of Architecture, Planning and Surveying, Universiti Teknologi MARA, Shah Alam 40450, Malaysia
}

\begin{abstract}
This paper proposed a theoretical design principle to enlivening waterfont space planning for crime prevention. Waterfront is usually the focal point of urban or port activity and became the symbiosis between water-related and urban-based functions. Increasing reports on crime problem have caused design, planning and development of waterfonts to be challenging and contentious. This study involved qualitative method and observation to Lumut Waterfront in Perak, Malaysia. Design approaches were identified based on crime prevention through environmental design (CPTED). Characteristics and criteria of CPTED were adapted to emphasise on public safety. It may be costly, but safety is more important.
\end{abstract}

(C) 2016. The Authors. Published for AMER ABRA by e-International Publishing House, Ltd., UK. This is an open access article under the CC BY-NC-ND license (http://creativecommons.org/licenses/by-nc-nd/4.0/).

Peer-review under responsibility of AMER (Association of Malaysian Environment-Behaviour Researchers), ABRA (Association of Behavioural Researchers on Asians) and cE-Bs (Centre for Environment-Behaviour Studies), Faculty of Architecture, Planning \& Surveying, Universiti Teknologi MARA, Malaysia.

Keywords: Crime Prevention; Environmental Design; Public Safety; Waterfront

\section{Introduction}

Waterfront is defined as a zone of interaction between urban development and the water. It is here that the needs of the water, the city, and its inhabitants come together. Breen \& Rigby (1994) sees waterfront as the water's edge in cities and towns while the water body may be a river, lake, ocean, bay, creek, or canal. On the other hand, Zhang (2002) characterized waterfront as a place that integrates land with water and has a natural attraction to people. The seashore and riverfront are said to be the most attractive water features for human settlement. It is common to develop land in front of water earlier than the inland areas in most countries.

Hussein (2006) defined an urban riverfront as a dynamic area where cities engage their shorelines. On the other hand, Dong (2004) described waterfront as a land fronting on to water. However, other researchers have different

\footnotetext{
* Corresponding author. Tel.: +6011 12830091; fax: +60355211564.

E-mail address: zaharah.yahya@salam.uitm.edu.my
}

2398-4287 @ 2016. The Authors. Published for AMER ABRA by e-International Publishing House, Ltd., UK. This is an open access article under the CC BY-NC-ND license (http://creativecommons.org/licenses/by-nc-nd/4.0/).

Peer-review under responsibility of AMER (Association of Malaysian Environment-Behaviour Researchers), ABRA (Association of Behavioural Researchers on Asians) and cE-Bs (Centre for Environment-Behaviour Studies), Faculty of Architecture, Planning \& Surveying, Universiti Teknologi MARA, Malaysia.

DOI: http://dx.doi.org/10.21834/e-bpj.v1i3.347 
preferences and use other different words such as such as city port, harbour front, riverside, river edge and riverfront (Hoyle, 2002; Hussein, 2006; Mann, 1973). Guo (1998) as cited in Dong (2004) described the waterfront as the area where water meets the land. The distance would be approximately 200 to 300 meters from the water line and one to two kilometres to the site. It may take within 20 minutes for walking distance.

Dong (2004) also cited Wu \& Gao (2002) who stated that waterfront area should have different features which incorporate each other. The area is usually surrounded by structural and non-structural objects to form a focal point. Waterfront is a public space, and this space is commonly shared and created for the community to accommodate a variety of activities without any discrimination or interferences (Kurniawati, 2012).

In 2015, the Royal Malaysian Police stated that there were increasing crime issues reported by the Malaysian public. The public has become more worried about their safety and this is said to lessen the quality of life. This has prompted the Malaysian government to launch programs to ensure the public safety. The public is also urged to be more aware of the surroundings and take safety precautions especially when they are in crowded public spaces such as at the waterfront. Thus, this research is carried out as there is a need to propose good design approaches to create well environmental surrounding for the safety of the public.

\section{Aim and Objectives}

This paper analyses crime prevention through design on the waterfront and to investigate the strategy in design and typology of waterfront in order to propose a theoretical design approach in view of public safety. The study assessed factors that caused crimes which are related to space planning concept. The research further examined Crime Prevention through Environmental Design (CPTED) theory and how to adapt the theoretical principle of CPTED design framework to an existing waterfront in Lumut, Perak.

\section{Crime Prevention effort in Malaysia}

Sakip \& Abdullah (2012) state that Crime is a worldwide issue. Every demonstration of crime is different in terms of the desired incentive. It includes three environmental elements that happen at the same time, in particular: (i) the focused on casualty either an individual, a gathering or property, (ii) the offender party with the inspiration to strike the offense, and (iii) the feeling of the chance to carry out crime. Based on Marvi \& Behzadfar, (2015), Crime has been characterized as a demonstration deserving of law, as being prohibited by statute or harmful to the general population welfare; a malevolent or damaging act; an offense, a transgression, particularly of a grave character. The Malaysian government and its police force have organized several measures to reduce crime such as the "Crime Prevention Campaign", creating "Mobile Police Bit / Station", "Rakan Cop (Malay: Friends of Cops)", patrolling the neighbourhoods and few other programs (Marzbali, Abdullah, Razak \& Tilaki, 2012). These programs were introduced to reduce the crime rate statistic and increase fear of committing crime and they are conducted especially at hotspot areas with high crime rates. Most police officers are also involved to patrol the neighbourhood areas. This will enable them to communicate directly with the society and make them feel safe and secured. However, it should be noted that the society should also participate in most of these programs and be more caring and concerned of their neighbours. These programs have proven to give positive impacts on reducing crime.

\section{The theory of Crime Prevention through Environmental Design (CPTED)}

The original idea of CPTED was said to be pioneered by Jane Jacob's The Death and Life of Great American Cities in 1961. The CPTED theory is an acronym for Crime Prevention through Environmental Design described by Crowe (2000) as, "the proper design and effective use of the built environment can lead to a reduction in fear and incidence of crime, and an improvement in the quality of life". CPTED was developed by C. Ray Jeffery in his writing entitled Crime Prevention through Environment Design (CPTED) in 1971. The concept was further refined by an architect, Oscar Newman in his manuscript Defensible Space: Crime Prevention through Urban Design in 1972. Table 1 showed some of the works related to CPTED. The basic idea of CPTED is to propose steps and rules on crime prevention. The study includes on how to overcome crime opportunity and reduce fear among the public. The 
CPTED study was recognised from the mid-twentieth century, and the idea has been further developed by many researchers, planners, and designers (Cozens \& Love, 2015).

\section{Approaches to CPTED theory}

Based on Table 1, in 1960 Wood initiated an idea in providing guidelines for addressing security issues. The idea was then further developed and in 1971, Jeffery who was a criminologist proposed and formulated CPTED but with a rather limited scope compared to Newman. Both of them developed on previous works by Elizabeth Wood (1961), Jane Jacobs (1961) and Shlomo Angel (1968) theories. Jeffery was said to have over thought about the social causes of crime and made general arguments that crime prevention should focus on factors related to the biology of crime, such as exposure that could lead to brain damage and delinquency in children. He also proposed on reducing the environmental opportunities for crimes such as sub-cultural influences.

Table 1: CPTED timeline

\begin{tabular}{|c|c|c|c|c|c|}
\hline 1960 & 1961 & 1968 & 1971 & 1972 & 1991 \\
\hline Elizabeth Wood & Jane Jacobs & Schlomo Angel & C. Ray Jeffery & Oscar Newman & Timothy D Crowe \\
\hline $\begin{array}{l}\text { - Guidelines for } \\
\text { addressing security } \\
\text { issue } \\
\text { - Work with Chicago } \\
\text { Housing Authority } \\
\text { - Emphasis on } \\
\text { design feature of } \\
\text { building }\end{array}$ & $\begin{array}{l}\text { - The Death and } \\
\text { Life of Great } \\
\text { American Cities } \\
\text { - Argued that } \\
\text { neighbourhoods } \\
\text { should be isolated } \\
\text { from one another } \\
\text { - Develop a social } \\
\text { framework that the } \\
\text { cities needed an } \\
\text { effective self- } \\
\text { policing system } \\
\text { - Attributes } \\
\text { clear boundary of } \\
\text { public and private } \\
\text { spaces } \\
\text { viciousness of use } \\
\text { high level of } \\
\text { pedestrian use of } \\
\text { the sidewalks }\end{array}$ & $\begin{array}{l}\text { - Discouraging } \\
\text { Crime Through } \\
\text { City Planning } \\
\text { study of street } \\
\text { crime in Oakland } \\
\text { - Crime was } \\
\text { inversely related } \\
\text { to the level of } \\
\text { activity on the } \\
\text { street } \\
\text { The commercial } \\
\text { strip environment } \\
\text { was particularly } \\
\text { vulnerable to } \\
\text { crime because it } \\
\text { thinned out activity } \\
\text { Making it easier } \\
\text { for individuals to } \\
\text { commit street } \\
\text { crime }\end{array}$ & $\begin{array}{l}\text { - Crime prevention } \\
\text { through } \\
\text { environmental } \\
\text { design } \\
\text { criminologist from } \\
\text { Florida State } \\
\text { University } \\
\text { - In this project, he } \\
\text { attempted to } \\
\text { control the school } \\
\text { environment of } \\
\text { juveniles in the } \\
\text { area } \\
\text { - His approach tied } \\
\text { in closely with the } \\
\text { psychological } \\
\text { learning theory of } \\
\text { B.F. Skinner } \\
\text { - Jeffrey's concepts } \\
\text { of CPTED were } \\
\text { ignored } \\
\text { throughout the } \\
\text { 1970's }\end{array}$ & $\begin{array}{l}\text { - Defensible Space } \\
\text { - Crime Prevention } \\
\text { through Urban } \\
\text { Design } \\
\text { - This book } \\
\text { discussed the } \\
\text { connection of } \\
\text { crime and the } \\
\text { physical form of } \\
\text { building instead of } \\
\text { environmental } \\
\text { control } \\
\text { - First, allow people } \\
\text { to see and be } \\
\text { seen continuously } \\
\text { - Attributes } \\
>\text { Natural Access } \\
\text { Control } \\
>\text { Natural } \\
\text { Surveillance } \\
\text { Territoriality }\end{array}$ & $\begin{aligned} \text { - } & \text { CPTED } \\
& \text { approach have } \\
& \text { gained wide } \\
& \text { international } \\
& \text { acceptance due } \\
& \text { to law } \\
& \text { enforcement } \\
\text { Attributes } & \text { Territoriality } \\
> & \text { Natural } \\
& \text { surveillance } \\
> & \text { Access control } \\
> & \text { Image } \\
> & \text { Conflicting user } \\
& \text { group } \\
> & \text { Activity support } \\
> & \text { Crime } \\
& \text { generators } \\
> & \text { Land use mix } \\
> & \text { Movement } \\
& \text { predictors } \\
> & \text { Cohesion } \\
> & \text { Connectivity } \\
> & \text { Capacity } \\
> & \text { Culture }\end{aligned}$ \\
\hline
\end{tabular}

On the other hand, Newman focused his study on the high crime rates in public housing projects highlighted on their design problems. He did not agree with the large, inhuman scale of any housing developments as these create difficulty for residents to identify and differentiate between their neighbours and intruders. Inability to recognise intruder or trespasser may cause potential criminal to commit crime without any fear of arrest. The study showed how physical design contributed to victimization by criminals. Newman and other architects such as Richard Gardiner (1978), also put forward a wide range of other detailed design suggestions to change these weaknesses and make housing area safer. According to Newman, the main purpose of the "Defensible Space" was to encourage natural territorial behaviour in residents by enabling them to give surveillance to their individual residences and public spaces. This concept was further expanded by Timothy D Crowe in 1990 into a comprehensive set of guidelines to reduce crime in the built environment. It was intended to guide police, town planners and architects. These guidelines have been publicized in hundreds of training sessions conducted by Crowe and others throughout the United States, and the approach is known as CPTED. 


\section{CPTED theory in Malaysian Context}

According to the Department of Town and Country Planning Malaysia (DTCPM) in 2012, CPTED concept Implementation Guide in Malaysia is prepared to support the "Implementation of Environmental Design for Safe City" (Measure 2) based on Strategy 1: Environmental Design Initiatives, Safe City Program 2010. This guide contains a summary of concepts, general guidelines and a CPTED check-list. This check-list can be used as a guide during the preparation and checking of development layout plans and building plans as well as evaluating the progress and implementation of projects on the site.

\section{Typology study}

Based on previous studies, CPTED have received much attention from many researchers. Table 3 demonstrates design elements approach to avoid crime issue. These environmental design approach to crime prevention will be implemented in the earlier design stage.

Table 2: CPTED Concept Implementation Guide in Malaysia (DTCPM, 2012)

\begin{tabular}{|l|l|}
\hline \multicolumn{1}{|c|}{ Attributes } & \multicolumn{1}{c|}{ Description } \\
\hline $\begin{array}{l}\text { Territoriality } \\
\text { Reinforcement }\end{array}$ & $\begin{array}{l}\text { To increase the awareness of the public through 'eyes on the street' approach towards the criminal and thus reduce } \\
\text { confidence of the criminal to commit the crime. } \\
\text { The ability of the environment to create a clear and wide opportunity for surveillance from various angles, whether } \\
\text { indoor or outdoor, by the residents or security guards through design and location of windows, lobbies or doors of } \\
\text { buildings. }\end{array}$ \\
\hline $\begin{array}{l}\text { Maintenance and } \\
\text { Management }\end{array}$ & $\begin{array}{l}\text { To emphasize the need to maintain and manage the area and buildings regularly and continuously by the } \\
\text { management, occupants, owners and community. The presence of a deteriorated or abandoned site or building can } \\
\text { breed criminal activities such as drug addiction and other anti-social activities. }\end{array}$ \\
\hline $\begin{array}{l}\text { Natural Access } \\
\text { Control }\end{array}$ & $\begin{array}{l}\text { To prevent a person from entering an area or premises where he should not be. Access control can be implemented } \\
\text { through the use of doors with security cards, fencing, landscaping and other physical means. }\end{array}$ \\
\hline
\end{tabular}

Table 3: Typology study

\begin{tabular}{|c|c|c|}
\hline Typology & Description & Elements \\
\hline $\begin{array}{l}\text { Pattern of } \\
\text { Waterfront } \\
\text { Development }\end{array}$ & $\begin{array}{l}\text { Waterfronts are powerful places by nature. Good waterfront comes from good } \\
\text { planning and layout. There are some pattern of waterfront development that can } \\
\text { be applied to planning of waterfront. }\end{array}$ & $\begin{array}{l}\text { 1. Settlement } \\
\text { 2. Port } \\
\text { 3. City detaches } \\
\text { 4. Rediscover }\end{array}$ \\
\hline Water edges & $\begin{array}{l}\text { In urban development, the urban component plays a vital role in reconnecting all } \\
\text { the urban points in city planning. Water edges become a place to assemble and } \\
\text { have activities. }\end{array}$ & $\begin{array}{ll}\text { 1. } & \text { Sloping edge } \\
\text { 2. } & \text { Tiered } \\
\text { 3. } & \text { Stepped edge } \\
\text { 4. } & \text { Boating deck } \\
\text { 5. } & \text { Pedestrian Bridge }\end{array}$ \\
\hline Linkages & $\begin{array}{l}\text { Linkage signifies "connection" — the demonstration of connecting or the certainty } \\
\text { of being linked - specifically the sort of relationship where one thing takes after } \\
\text { another. }\end{array}$ & $\begin{array}{l}\text { 1. Promenade } \\
\text { 2. Corridor } \\
\text { 3. Cafeteria }\end{array}$ \\
\hline Waterfront & $\begin{array}{l}\text { Waterfront can be described as open space along waterways in cities; increased } \\
\text { public access to waterfront areas; development of waterfront parks. The program } \\
\text { that are located in waterfront can influence the behaviour of the user and safety. }\end{array}$ & $\begin{array}{ll}\text { 1. } & \text { Event canopy } \\
\text { 2. Sculptured pedestrian terrain } \\
\text { 3. Technology boulevard } \\
\text { 4. Water curtain digital projection } \\
\text { 5. Recreational barge } \\
\text { 6. Lookout platform } \\
\text { 7. Underpass occupier } \\
\text { 8. Vertical resurfacing } \\
\text { 9. Floating exhibition } \\
\text { 10. Mobile games pavilion } \\
\text { 11. Reforestation groove }\end{array}$ \\
\hline
\end{tabular}




\begin{tabular}{|l|l|l|}
\hline Public Realm & $\begin{array}{l}\text { Public realm is used by everyone. The public realm constitutes the next most } \\
\text { permanent component of the built landscape. It can either be a shared city, } \\
\text { waterfront or promenade and can be defined by both the private and public } \\
\text { buildings that made-up the streetscapes, parks, square and plazas. }\end{array}$ & $\begin{array}{l}\text { 1. In between building } \\
2 . \text { Canal as public realm } \\
\text { 3. Gound floor as public realm } \\
4 . \text { Upper and lower building as } \\
\text { public realm. }\end{array}$ \\
\hline Street light & $\begin{array}{l}\text { Passages need to be clearly visible whether in daylight or night. The selection of } \\
\text { street lighting needs to be considered as to make the street feel safer for the } \\
\text { user. }\end{array}$ & $\begin{array}{l}\text { 1. Lighting of parks } \\
2 . \text { Lighting under bridge } \\
\text { 3. Lighting of spotlight } \\
4 . \text { Lighting of promenade }\end{array}$ \\
\hline
\end{tabular}

\section{Methodology}

This study begins with a brief overview of the literature on CPTED, followed by comparative studies on different theories of CPTED. The study further constructed a framework to compare the theory of CPTED that can be applied to Waterfront area. Related information requirements on CPTED are assessed using keywords and phrases on the Internet. The Internet has the potential to be an effective tool to help find related information as there is a huge diversity of available information. However, the information on the Internet is open and unregulated with various quality of content. These types of references may be used as information tools. Books on CPTED also become major references for this. This study explored on the design elements and environmental planning of Lumut Waterfront in Perak.

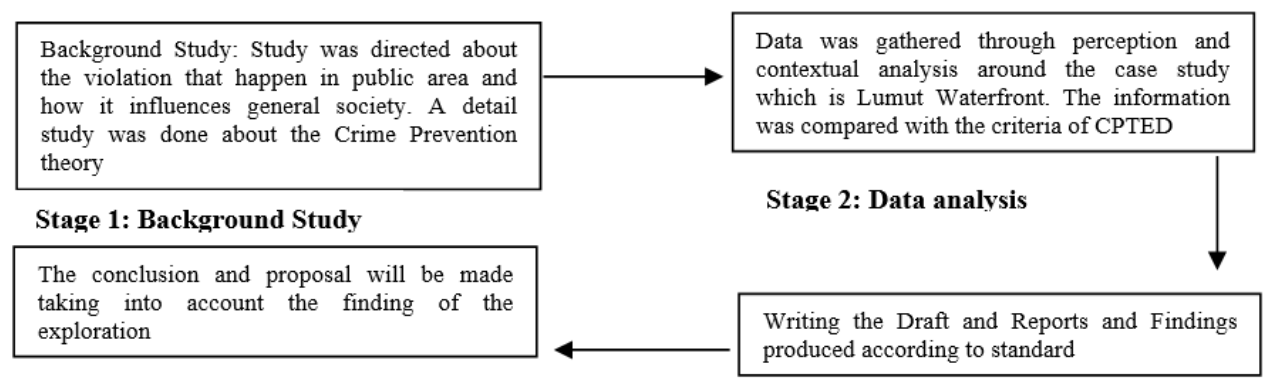

Stage 4: Conclusion and recommendation
Stage 3: Writing Un

Figure 2: Classification of research progress

\section{Site visit and precedent study}

Previous studies were carried to various existing waterfronts and promenades in Malaysia to gather information. For the case study, observations were be made to four sections of the waterfront in Lumut. The study compared elements contained in CPTED Design approach to the existing sites and examined any possibilities of better design approach for the waterfront. Interviews were also conducted with the public who were at the waterfront. As the concept of CPTED requires social interaction in determining its effectiveness towards crime prevention (Cozens et al., 2005), interviewing visitors and users of the waterfront could assist the study in obtaining information on their perception and preferences for the design and planning of the waterfont. The information from visitors and users are important to support measurement taken from observations (Sakip \& Abdullah, 2012).

\section{Findings and Discussions}

Development of case study - Lumut Waterfront 
Figure 3 shows the layout of Lumut Waterfront project that is divided into four main segments. The segments are Marina Wing, Esplanade Wing, Jetty Wing and Maritime Wing. The development area for Lumut Waterfront is approximately 36.25 acres, and it covers about $1.7 \mathrm{~km}$ of Sungai Dinding. The development was completed in 2010. This waterfront known as the "Jaluran Lumut Waterfront" that is located at the Tourism and Maritime Town of Lumut. The waterfront area is surrounded by commercial buildings and public spaces.

Each segment is developed with different architectural approaches and concepts to suit with the overall master planning. The activity and design are continuous for each different segments. Based on previous studies, the researchers identified several important aspects related to the CPTED. The data presented in Table 4 are findings based on the elements of CPTED, observed for the site.

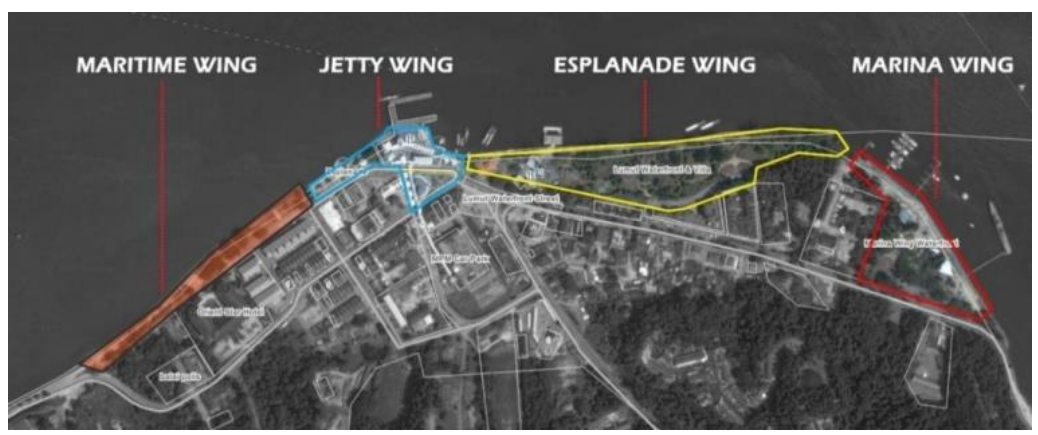

Figure 3: Location of Lumut waterfront Source: Google Maps. (2016). Lumut township

a)Territoriality

Table 4: CPTED at Lumut waterfront - Territoriality

\begin{tabular}{|c|c|}
\hline \multicolumn{2}{|c|}{$\begin{array}{l}\text { CPTED - Territoriality } \\
\text { - Territorial reinforcement is utilized to separate open and private space. } \\
\text { - This should be possible by using various signage, flower beds and others. } \\
\text { - It is to demonstrate that somebody claims and thinks about this space. } \\
\text { - Space is not fully utilized for park excitement, as some of the area were identified to potentially be utilized for some illegitimate, } \\
\text { illicit or undesirable movement. }\end{array}$} \\
\hline Marina Wing & \multirow[t]{2}{*}{$\begin{array}{l}\text { - Colour, shape, massing, and style make the territoriality existed. } \\
\text { - Some of the fences are too low and provide opportunity for burglary. }\end{array}$} \\
\hline Jetty Wing & \\
\hline Esplanade Wing & $\begin{array}{l}\text { - Space is not fully utilized } \\
\text { - Many negative spaces can be seen }\end{array}$ \\
\hline \multicolumn{2}{|c|}{$\begin{array}{l}\text { Discussion } \\
\text { Territoriality concept can be easily adapted in Marina Wing and Jetty Wing areas. Public areas can adapt the principle naturally or to } \\
\text { be done by the developer. }\end{array}$} \\
\hline
\end{tabular}

b) Natural surveillance

Table 5: CPTED at Lumut waterfront - Natural Surveillance

CPTED - Natural Surveillance
- The surrounding area is open and visible from far.
- User can enjoy using the recreation area, trail path or play area.




\begin{tabular}{|l|l|}
\hline Marina Wing & $\begin{array}{l}\text { - Buildings have clear vision because less vegetation around that area. } \\
\text { - There is no negative area i.e. hidden areas from pedestrian and other users from parking area. }\end{array}$ \\
\hline Jetty Wing & $\begin{array}{l}\text { - Limited visible area because of too much vegetation. } \\
\text { - Waterfront stretch is too long. }\end{array}$ \\
\hline Esplanade Wing & \multicolumn{1}{c|}{ Discussion } \\
The vegetations around the playground are good for giving shade but they must be maintained and trimmed to create better \\
sightlines for parents who are observing their children.
\end{tabular}

\section{c) Access Control}

Table 6: CPTED at Lumut waterfront - Access Control

\begin{tabular}{|l|l|}
\hline $\begin{array}{l}\text { CPTED - Access Control } \\
\text { - Provide common access for entry and exit using wall or flower bed. } \\
\text { - Suggest fence or a way path. } \\
\text { - Safe monitoring such as using CCTV. }\end{array}$ \\
\hline Marina Wing & $\begin{array}{l}\text { - Most of the public realm do not have CCTV but already have safety precaution such as post guard. } \\
\text { Jetty Wing }\end{array}$ \\
\hline Esplanade Wing & - There is no guard or patrol at this waterfront. \\
\hline $\begin{array}{l}\text { The majority of the premises nearby the Waterfront area have safety access control such as door and lock but no CCTV. Same goes } \\
\text { to Waterfront area. }\end{array}$ \\
\hline
\end{tabular}

\section{d) Supporting Activity Area}

Table 7: CPTED at Lumut waterfront - Supporting Activity Area

\begin{tabular}{|l|l|}
\hline $\begin{array}{l}\text { CPTED - Supporting Activity Area } \\
\text { - Activity space such as barbecue area must be considered to have better sightlines. } \\
\text { - Facilities provided should be within walking distance. }\end{array}$ \\
\hline Marina Wing & $\begin{array}{l}\text { - Area for activities are located near to the each other and have good sightlines. } \\
\text { - Some facilities are situated near to each other and less prone to crime problems. }\end{array}$ \\
\hline Jetty Wing & - Less activity happens here. \\
\hline Esplanade Wing & No buildings such as toilet or commercial lots. \\
\hline $\begin{array}{l}\text { The facilities provided are important for the residents and must be planned carefully to minimize the crime opportunity. The other } \\
\text { supporting areas should also be planned carefully. }\end{array}$ \\
\hline
\end{tabular}

e) Image

Table 8: CPTED at Lumut waterfront - Images

CPTED - Image

- To have a good image, the maintenance and management must be considered.

- Good maintenance ensure better building condition and safety. 


\begin{tabular}{|l|l|}
\hline Marina Wing & $\begin{array}{l}\text { - Most of the public area have good image but some of them remain empty because of high rental rates. } \\
\text { Jetty Wing }\end{array}$ \\
\hline Esplanade Wing & $\bullet$ Many gazebo and playground areas are damaged. \\
\hline \multicolumn{1}{c|}{$\begin{array}{c}\text { Discussion } \\
\text { Most of the commercial spaces are well maintained but some are not and resulted in giving bad image. Some of the building are } \\
\text { isolated and damaged. These have given bad images and provide spaces for committing crime. }\end{array}$} \\
\hline
\end{tabular}

\section{f) Maintenance and management}

Table 9: CPTED at Lumut waterfront - Maintenance and Management

\begin{tabular}{|c|c|}
\hline \multicolumn{2}{|c|}{$\begin{array}{l}\text { CPTED - Maintenance and management } \\
\text { - Should be well maintained to prevent any unforeseen possibility for crime. }\end{array}$} \\
\hline Marina Wing & \multirow[t]{2}{*}{$\begin{array}{l}\text { - Most of the public area have good image but some of them remain empty because of high rental rates. } \\
\text { - The owners for kiosks and some facilities do not carry out proper maintenance. }\end{array}$} \\
\hline Jetty Wing & \\
\hline Esplanade Wing & - Not well maintained. \\
\hline
\end{tabular}

\section{g) Developing a theoretical framework for crime prevention design of Lumut waterfront}

Based on the study, there are seven identified components that can be implemented using the CPTED strategy and concept. The components are as shown in Table 10.

Table 10: Theoretical Framework for crime prevention design of Lumut waterfront

\begin{tabular}{|l|l|}
\hline General framework & \multicolumn{1}{c|}{ Description } \\
\hline Layout Design & $\begin{array}{c}\text { I. Mixed development } \\
\text { The mixed development consists of residential, commercial, industrial and public space development } \\
\text { activities. Mixed development is strongly encouraged to create an active and busy environment throughout } \\
\text { the day. The objective of mixed development activates the area with various land use activities such as } \\
\text { residential activities, shops, restaurants, public space, cultural activities, and recreational activities. Create } \\
\text { natural surveillance and improve security in the area especially in places with high risk of crime. Increase the } \\
\text { sense of belonging and awareness of the community and environment. } \\
\text { II. Activity Generation } \\
\text { Encourage activities that could draw people's attention such as night market, alfresco café, restaurants, } \\
\text { sports and recreation, and so on. The objective of these activities is to enhance the safety of the } \\
\text { surroundings and act as natural street approach surveillance. } \\
\text { III. Avoid remote spot and dead end } \\
\text { Entrapment spots are spaces that are deserted, isolated and surrounded. Designs should avoid creation of } \\
\text { entrapment spots especially in car parks, pedestrian walkways, dead-end roads or back lanes. The objective } \\
\text { of avoiding remote spot and dead end is to prevent hideout for criminal and threat from criminal or intruders } \\
\text { IV. View of spaces } \\
\text { Provide clear, maximum and unobstructed views of spaces at short and long distances, especially for areas } \\
\text { surrounding the pedestrian walkways. Large pillars, fences that are not transparent, poorly maintained shrubs } \\
\text { and other obstacles near the pedestrian walkways can create hideouts for criminals or intruders as they could } \\
\text { threaten or attack the public. The objective of view space is to facilitate the detection of criminal and reduce } \\
\text { the fear of becoming a victim of crime. }\end{array}$ \\
\hline
\end{tabular}




\begin{tabular}{|c|c|}
\hline $\begin{array}{l}\text { Access and } \\
\text { Pedestrian } \\
\text { Walkways }\end{array}$ & $\begin{array}{l}\text { Access includes roads and pedestrian walkways such as tunnels, pedestrian bridges and narrow lanes. } \\
\text { Isolated and narrow pedestrian tunnels should not be allowed in new development areas. However, for } \\
\text { existing pedestrian tunnels, overhead bridges and narrow lanes, security measures such as adequate lighting } \\
\text { and installation of safety mirrors must be implemented. Use of clear signage as a direction indicator and } \\
\text { reminder has to be planned in an integrated manner so that the user is not confused and is wary of the } \\
\text { surrounding area. The objective of "Access and Pedestrian Walkways" is to prevent or reduce road and } \\
\text { pedestrian walkways that are separated, quiet, hidden and trapped. }\end{array}$ \\
\hline $\begin{array}{l}\text { Soft and Hard } \\
\text { Landscaping and } \\
\text { Urban Design } \\
\text { Elements }\end{array}$ & $\begin{array}{l}\text { The use of soft landscaping (trees, shrubs, tree fences and vegetation ground cover) and elements of urban } \\
\text { design / hard landscaping covers all types of manmade structures such as street furniture's, pedestrian } \\
\text { walkways, gazebos, fountains, garden lamps, statues and so on. They can be used to determine public and } \\
\text { private boundaries by reference to the National Landscape Guidelines 2008. The objective of Soft and hard } \\
\text { landscaping and other Urban Design Elements are to create an environment that is user-friendly, safe and } \\
\text { attractive. These elements can also be used as barriers to prevent snatch theft and act as border separators, } \\
\text { junction indicators, behind indicators and directional guides. }\end{array}$ \\
\hline Car parks & $\begin{array}{l}\text { The provision of parking areas should emphasize on safety measures such as car parking lots facing towards } \\
\text { business premises and has good lighting. The objective is to increase safety and reduce criminal incidents } \\
\text { and increase natural surveillance. }\end{array}$ \\
\hline Lighting & $\begin{array}{l}\text { The provision of bright lighting, especially at night, allows an individual to be able to see or be seen clearly. } \\
\text { Bright lighting can reduce public fear especially in car parks, bus stops, ATMs and so on. Lighting should be } \\
\text { at a level that allows a person's facial features to be identified in normal vision and assist the CCTV system to } \\
\text { monitor crime areas more effectively. The objective is to prevent existence of dark and dimmed space and } \\
\text { enable criminals or intruders to be easily recognized and identified. }\end{array}$ \\
\hline Security Devices & $\begin{array}{l}\text { Security devices include safety mirror, security alarm, CCTV and warning sign boards. The objective is to } \\
\text { provide reminder, awareness and warning to the public to be vigilant. }\end{array}$ \\
\hline $\begin{array}{l}\text { Management and } \\
\text { maintenance }\end{array}$ & $\begin{array}{l}\text { Areas belonging to residential, commercial, industrial, infrastructure and utilities, and places of public } \\
\text { concentration which are owned by the government, government agencies, personal and private sectors } \\
\text { should be maintained regularly and periodically to enhance the level of safety. For example, pruning of lush } \\
\text { trees, clearing of bushes that obstruct lighting, CCTV and public view, and also rehabilitation of areas / } \\
\text { buildings that are abandoned. The objective is to prevent the existence of dilapidated and abandoned area or } \\
\text { building and enhance safety level. }\end{array}$ \\
\hline
\end{tabular}

\section{Conclusion}

Identification of appropriate design and space planning for public spaces such as waterfront area is essential to create a fun, recreational leisure area for people to enjoy but safe from crime. Based on the finding of this research, there are seven principles based on Crime Prevention through Environmental Design (CPTED) that can be adopted and adapted to waterfront. These adapted principles may induce an environment where crime opportunity could be reduced and encouraging for the public to feel safer. The implementation of these principles may be costly, but the safety of the community is priceless.

\section{Acknowledgements}

The authors would like to thank the Institute of Research Management \& Innovation and Faculty of Architecture, Planning and Surveying of Universiti Teknologi MARA for its Grant.

\section{References}

Angel, S. (1968). Discouraging Crime through City Planning. Berkeley, CA: Center for Planning and Development Research, University of California at Berkeley. 
Breen, A., \& Rigby, D. (1994). Waterfronts: Cities reclaim their edge. United State: McGraw-Hill.

Crowe, T. D. (1991, 2000). Crime Prevention through Environmental Design: Applications of Architectural Design and Space Management Concepts. Butterworth-Heinemann.

Cozen, P. \& Love, T (2015) A Review and Current Status of Crime Prevention through Environmental Design (CPTED). Journal of Planning Literature, $1-20$

Cozen, P. M. Saville, G \& Hillier, D. (2005) Crime prevention through environmental design (CPTED): a review and modern bibliography. Property Management Vol 23 No.5, 328-356

Dong, L. (2004). Waterfront Development : A case study of Dalian, China. Unpublished Master Thesis, University of Waterloo, Canada. Retrieved December 2015, from uwspace.uwaterloo.ca/bitstream/10012/988/1/l2dong2004.pdf.

DTCPM, Department of Town and Country Planning Malaysia (2012) Rekabentuk Bandar Selamat: panduan Pelaksanaan. Retrievd January 2016 from http://www.townplan.gov.my/download/Penerbitan/NKRA/GP_CPTED\%20Eng\%20Version_2nd.pdf

Gardiner, R. (1978) Design for Safe Neighborhoods—-the Environmental Security Planning and Design Process. Washington, DC: National Institute of Law Enforcement and Criminal Justice, Law Enforcement Assistance Administration, United States Department of Justice.

Google Maps. (2016). Lumut township. Retrieved January 2016 from: https:/www.google.com.my/maps/place/Lumut,+Perak/

Hoyle, B. (2002). Urban waterfront revitalisation in developing countries: The example of Zanzibar's Stone town. The Geographical Journal, $168(2), 141-162$.

Hussein, H. (2006). Urban recreational riverfronts: Successful revitalization elements. Journal of Design and the Built Environment, I(2).

Jacobs, J. (1961). The Death and Life of Great American Cities. London, UK: Jonathon Cope.

Jeffery, C. (1971). Crime Prevention through Environmental Design. Beverly Hills, CA: Sage.

Mann, R. (Ed.). (1973). Rivers in the City. Newton Abbot: David \& Charles.

Marzbali, M. H., Abdullah, A., Razak, N. A., \& Tilaki, M. J. M. (2012). The influence of crime prevention through environmental design on victimisation and fear of crime. Journal of Environmental Psychology, 32(2), 79-88.

Marvi, L. T. \& Behzadfar, M. (2015). Local Sustainability with Emphasis on CPTED Approach, the case of Ab-kooh Neighborhood in Mash-had Procedia - Social and Behavioral Sciences, 201, $409-417$

Newman, O. (1972). Defensible Space: Crime Prevention through Urban Design. New York: Macmillan.

Sakip, S.R.M, \& Abdullah, A. (2012). "An Evaluation of Crime Prevention Through Environmental Design (CPTED) Measures in a Gated Residential Area: A Pilot Survey", Asian Journal Of Environment-Behaviour Studies, Volume 3, Number 10, October.

Kurniawati, W. (2012). "Accommodative study of public space for marginalized people", Asian Journal Of Environment-Behaviour Studies, Volume 3, Number 10.

Wood, E. (1961). Housing Design: A Social Theory. New York: Citizens, Housing and Planning Council of New York

Zhang, L. (2002). An evaluation an urban riverfront park, Riverfront park, Spokane, Washington experience and lessons for designer. Unpublished Master Thesis. Washington State University, US. Retrieved January 2016 from http://www.dissertations.wsu.edu/Thesis/Spring2002/L_Zhang_050602.pdf 